\title{
Award-winning papers in 2014
}

Papers published in Municipal Engineer are eligible for awards from the Institution of Civil Engineers. Papers from any of the ICE journals can be nominated for several awards. In addition, each journal has awards dedicated to their specific subject area.

On Friday 9 October 2015, ICE president David Balmforth presented awards to the following papers published in Municipal Engineer in 2014. The editorial panel nominated their best papers and an awards committee chaired by Quentin Leiper allocated the awards.

\section{James Hill Fund Award}

The James Hill Fund Award, presented for the best paper on a municipal engineering subject, was awarded to Kennedy-Walker et al. (2014).

\section{Abstract}

Improvements in the collection and treatment of sewage are critical to reduce health and environmental hazards in rapidly urbanising informal settlements. Where sewerage infrastructure is not available, road-based faecal sludge management options are often the only alternative. However, the costs of faecal sludge transportation are often a barrier to its implementation and operation and thus it is desirable to optimise travel time from source to treatment to reduce costs. This paper presents a novel technique, employing spatial network analysis, to optimise the spatiotopological configuration of a road-based faecal sludge transportation network on the basis of travel time. Using crowd-sourced spatial data for the Kibera settlement and the surrounding city, Nairobi, a proof-of-concept network model was created simulating the transport of waste from the 158 public toilets within Kibera. The toilets are serviced by vacuum pump trucks which move faecal sludge to a transfer station, and from there a tanker transports waste to a treatment plant. The model was used to evaluate the efficiency of different network configurations, based on transportation time. The results show that the location of the transfer station is a critical factor in network optimisation, demonstrating the utility of network analysis as part of the sanitation planning process.

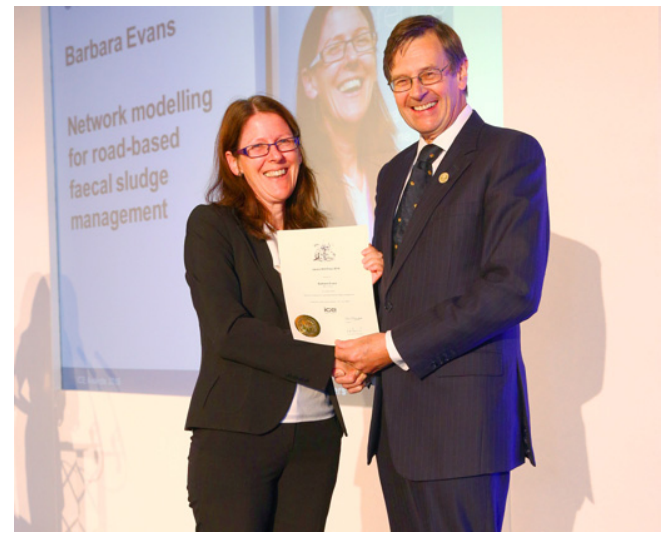

ICE President David Balmforth with James Hill Prize winner Barbara Evans

\section{Thomas Telford Premium Prize}

The Thomas Telford Premium Prize was awarded to Noble (2014).

\section{Abstract}

Faced with a set of daunting technical, conservation and budget challenges, in building a small extension onto a medieval church to serve the local community of Buckden, Cambridgeshire, UK, a group of retired civil engineers combined their experience to achieve a successful project outcome. Visitor and user facilities were squeezed into an extremely confined site, producing a development of exceptional quality. Using an innovative procurement route, the client formed its own limited company, directly employing the professional consultants on a design and build basis and taking on the project risks itself. Substantial savings were achieved by eliminating contractors' overhead costs and making extensive use of volunteer labour and expertise. The fact that the end user and contractor were the same people, having a deep understanding of client needs, helped in resolving a number of issues. These included the presence of ancient monuments, a diversity of interested parties and other complications. Work also included risk management, traditional external materials of stonework, lead and glazing for longevity, foundations of reinforced concrete ground slab and steel shell piles, temporary works, recycling and reuse of materials.

\section{REFERENCES}

Kennedy-Walker R, Holderness T, Alderson D, Evans B and Barr S (2014) Network modelling for road-based faecal sludge management. Proceedings of the Institution of Civil Engineers - Municipal Engineer 167(3): 157-165, http://dx. doi.org/10.1680/muen.13.00021.

Noble R (2014) Construction of Buckden's living stones rooms, Cambridgeshire, UK. Proceedings of the Institution of Civil Engineers - Municipal Engineer 167(4): 175-182, http://dx. doi.org/10.1680/muen.13.00002.

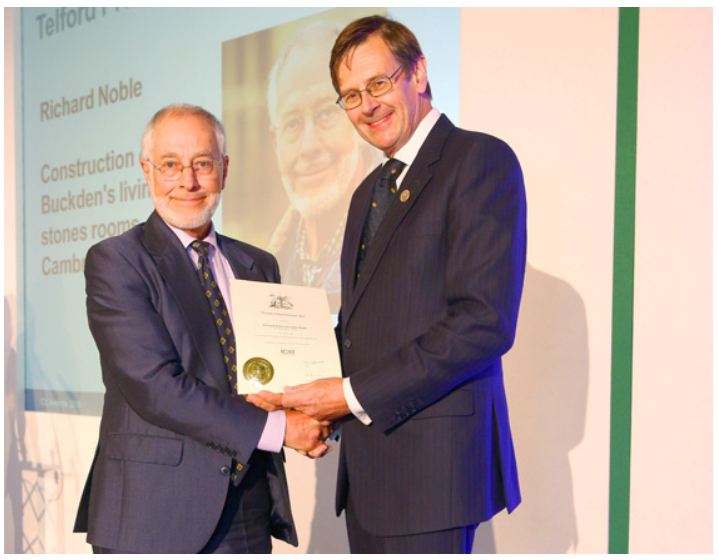

ICE President David Balmforth with Thomas Telford Premium Prize winner Richard Noble 